\title{
Reconstructing forest history from archaeological data: A case study in the Duero basin assessing the origin of controversial forests and the loss of tree populations of great biogeographical interest
}

\author{
Laura Hernández , Juan M. Rubiales , César Morales-Molino , Fernando Romero , Carlos Sanz , \\ Fernando Gómez Manzaneque
}

Departamento de Selvicuitura y Gestión Forestal Sastenible, CIFOR-INIA, Crta. La Cortina, km 7.5, 28040 Madrid, Spain

Departamento de Silvopascicuiama, Escueja Técnica Superior de ingenieros de Montes, Universidad Politécnica de Madrid, Ciudad universitaria, s/n, 28040 Madrid, Spain

Departamento de Prehistoria y Arqueologia, Universidad de Valladolid, C/Real de Bargos, s/n, 470! 1 Valladolid, Spain

Keywords:

Palaeoecology

Antlitacology

Iron Age II

Mediterramean pines

pims gr. sylvestris/nigia

Interglacial refugia

Forest management

Inland Spain

\section{Introduction}

Extensive changes in the landscape have been widely documented in the lberian Peninsula since the times of the Roman invasion, such as the impact of mining activities (Lewis and Jones, 1970), the introduction of plant varieties (e.g., Conedera et al., 2004; Gil et al., 2004) or the intensification of deforestation (Figueiral, 1995, 1996: Carrión et al., 2000, 2009; Rubiales et al., 2007; López-Sáez et al., 2009). In the northern Iberian plateau (inland Spain), where this study was performed, biogeographers have long addressed the interpretation of modern vegetal landscapes (Willkomm, 1896; Huguet del Villar, 1925: Font Quer, 1954; Calonge Cano, 1987; Franco Múgica et al., 2001, 2005; Gil and Torre, 2007), while historians have debated the nature and timing of human-induced changes in the vegetation cover over time (e.g., Hopfner, 1954; Schulten, 1963; Blanco Abril, 2003). Unfortunately, scientists have not yet come to a consensus regarding any of the proposed scenarios. The information from historical texts is neither regionally nor chronologically complete, especially prior to the Roman invasion. Despite the substantial amount of data on modern vegetation that exists today for southern Europe, no long-term studies on vegetation history are available in the area other than those of a palaeoecological nature. The palynological information for the Duero basin is restricted to a few lake systems and mires that hold Holocene records of past vegetation history (Franco Múgica et al., 2001, 2005). Conversely, the palaeoecological potential of archaeological charcoal remains is almost completely unexplored.

In this context, different hypotheses about the origin of the Mediterranean pinewoods in the area and their role in the longterm vegetation dynamics have been proposed, resulting in an interesting scientific debate among plant biogeographers (Rivas Martínez, 1987; Gil et al., 1990; Costa et al., 1997; López-Sáez et al., 2009). In fact, one of the largest Mediterranean pinewoods (Pinus pinaster Ait. and Pinus pinea L.) of the Iberian Peninsula has been found to be linked to the Duero basin sand dunes next to the study site analysed in this paper (Calonge Cano, 1987, 1998). Traditional 


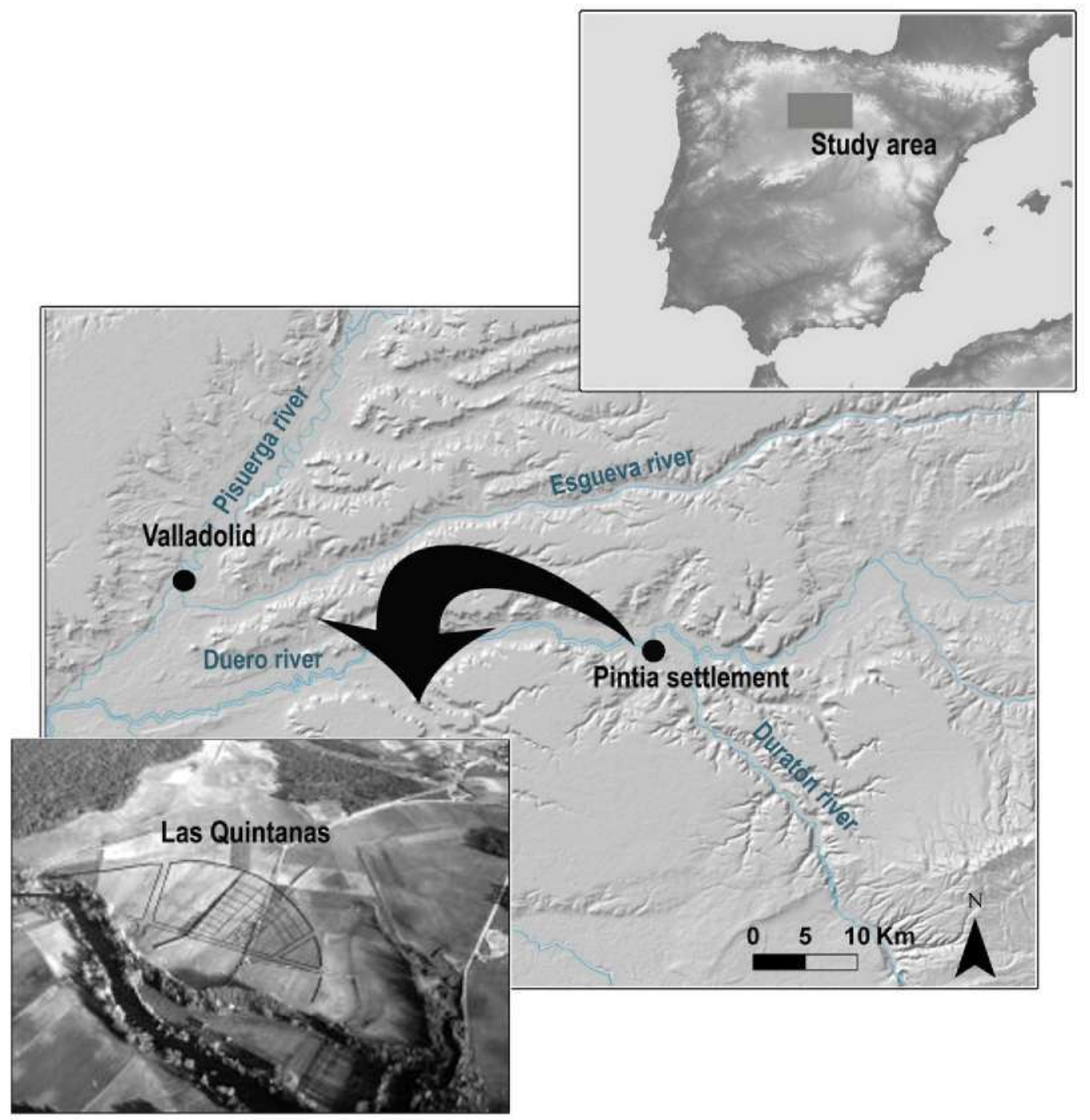

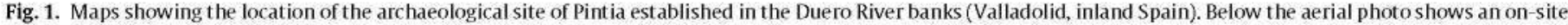
sketch of the archaeological area called "Las Quintanas" from which the charcoal assemblage came.

human use of some pinewood resources, like wood, resin and pine kernels, has probably influenced some geographers who have questioned the naturalness of the Mediterranean pine stands in the area (Hopfner, 1954; Bennassar, 1967; Navarro and Valle, 1987). Furthermore, the potential vegetation map based on phytosociological models indicates that these pine extensions would be occupied by Holm oak (Quercus ilex L.) instead of pines (Rivas Martínez, 2007). As a result, the presence of the Pinus species is not mentioned in the vegetation inventories in environmental technical works, and these pine stands are treated as merely exotic plantations. Consequently, one of the most important pine stands of the Iberian Peninsula is commonly relegated to an anthropogenic, secondary role. On the contrary, palaeoecological studies (García Antón et al., 1995; Costa et al., 1997; Franco Múgica et al., 2001, 2005), historical compilations (Gil, 1991) and other biogeographical and genetic works (Font Quer, 1954; Calonge Cano and Santos, 2006; Bucci et al., 2007) suggest completely different interpretations considering that these Mediterranean pinewoods are not only indigenous in the area but, more importantly, were stable throughout the Holocene.

This study provides detailed new information that fills a geographical gap in the central part of the Iberian plateau by applying on-site vegetation data from the analysis of a wood charcoal assemblage dating from the Iron Age II at the archaeological site of Pintia (Padilla del Duero, Central Spain). The combination of pre- vious works with the anthracological information should help reconstruct the forest landscape history of this zone during the lateHolocene. Moreover, this work presents knowledge of long-term ecological information as a useful tool to support forest management strategies. Forest history and ecology should be primary considerations in future decisions concerning forests.

\section{Materials and methods}

\subsection{Study area}

\subsubsection{Environmental setting}

The archaeological site of Pintia $\left(41^{\circ} 36^{\prime} 24^{\prime \prime} \mathrm{N}, 4^{\circ} 6^{\prime} 48^{\prime \prime} \mathrm{W}, 775 \mathrm{~m}\right.$ a.s.l.) is located close to the village of Padilla del Duero (Valladolid province) in the Spanish northern plateau (Fig. 1). This Vaccaean settlement was strategically sited in an area where different landforms offered protection, forest resources and land suitable for cultivation. Thus, the site was surrounded by a complex landscape where river buffers, sandy environments, swampy areas and limestone plateaus coexisted.

The most distinctive feature in this region is the sedimentary inland plains of the Duero Basin, which is bound by limestone plateaus $900 \mathrm{~m}$ high and the incised valleys created by fluvial erosion in the north and northeast. The sediments that fill the basin 
are sandy (mostly siliceous), but other tertiary loams and limestones can also be found. Interesting aeolian sand dunes that can be more than $10 \mathrm{~m}$ deep and whose origins date back to the quaternary (Diez-Herrero et al., 2002) can be found to the west and south of the study site.

The climate in this area of inland Spain is Continental-Mediterranean, with hard winters and approximately three months of summer drought. The mean annual temperature and rainfall are $11.9^{\circ} \mathrm{C}$ and $420 \mathrm{~mm}$ (S.I.G.A., http://sig.marm.es/siga/), respectively. The human activity that developed during the last millennia (mostly cereal cultivation and vineyards) left scattered remains of the original forests in the vicinity of the archaeological site. As a consequence, dispersed or fragmented stands of evergreen Holm-oak woods ( $Q$. ilex $\mathrm{L}$. subsp. ballota Samp. (Desf.)) together with Juniperus communis L. or Juniperus oxycedrus $\mathrm{L}$. can now be found in the area. Juniperus thurifera $L$. also grow in the limestone plateaus. In sites with moister soils and/or in the northern-oriented slopes, a small representation of deciduous forest (dominated by Quercus faginea Lam.) is detected. Deforestation was particularly intense in the fertile river banks, where riparian elements such as Ainus gitutinosa (L.) Gaertn., Ulmus minor Mill., Fraxinus angustifolia Vahl., Salix alba L., Salix eleagnos Scop.. Salix triandra L. and Tamarix spp. with helophytes like Pliragmites australis (Cav.) Steudel are currently rare. The high prevalence of pinewoods composed by $P$. pinaster and $P$. pinea linked to sandy soils has given the name of "Tierra de Pinares" ("Land of Pinewoods") to the area lying to the southwest of Pintia. These forests have been subject to intensive and traditional forest exploitation since the mid-19th century. The wood, the kernel, and especially the resin, were sources of income for the inhabitants of the area until the mid-20th century, when these products ceased to be profitable (Garcia Fernández, 2004).

\subsubsection{Archaeological site and chronology}

In its origins (Iron Age [I), the Pintia site was settled on both banks of the Duero River. The settlement, considered one of the first cities on the lberian Peninsula (Álvarez-Sanchis, 2005), covers 125 ha and consists of three differentiated parts: the fortified village called "Las Quintanas", where the studied charcoals come from, the "Carralaceña" artisan neighbourhood and the "Las Ruedas" necropolis (Sanz Minguez and Romero Carnicero, 2007). The chronology was established by relative dating based on the typology of the historical elements found in the sediments of the different layers and the radiocarbon dating of several elements, which consistently yielded two late-Holocene dates of $2640 \pm 30 \mathrm{BP}(2745-2770 \mathrm{cal}$ $\mathrm{BP})$ and $2470 \pm 30(2470-2700 \mathrm{cal} \mathrm{BP}) 1 \mathrm{sigma}$ calibration with the INTCAL09 dataset (Reimer et al., 2009).

The archaeological macro-remains recovered in the area of "Las Quintanas" cover five centuries of the settlement's history. The oldest levels ( 5 th-3rd centuries BC) belong to the Celtiberian (Vaccaean) ages, and the most modern level studied in this work coincides with a period of Roman rule over the lberian Peninsula (1st century BC and 1st century AD). An intermediate stage called the Sertorian stage (1st and 2nd centuries BC) characterised by Roman civil wars on the lberian Peninsula was also taken into account in the archaeological work.

\subsection{Anthracological analysis}

The present study is based on the analysis of 768 charcoal fragments that were manually collected by an archaeological team from the Valladolid University during the Pintia excavation work from 1998 to 2006.

The remains were found either scattered or in clusters throughout the three different archaeological layers of "Las Quintanas"
Table 1

Absolute trequencies of the charcoal fragments identified from the different archat ological layers of Pint ia. Taxa are ordered according to their abundance. The most abundant taxa in the charcoal assemblage are shown in bold.

\begin{tabular}{|c|c|}
\hline Taxa & No. fragments \\
\hline Pinus pinaster Ait. & 176 \\
\hline $\begin{array}{l}\text { Quercus subgen. Sclerophyllodris O. Schwarz (Quercus } \\
\text { Ilex L. type) = evergreen Quercus type }\end{array}$ & 127 \\
\hline $\begin{array}{l}\text { Quercus subgen. Quercus Oested = deciduous Quercus } \\
\text { type (Quercus faginea Lam. and Quercus pyrenaica } \\
\text { Wild. type) }\end{array}$ & 121 \\
\hline Juniperus spp. & 120 \\
\hline Pinus gr, sylvestris/nigra & 117 \\
\hline Pinus ge pinasterjpinea & 32 \\
\hline Hex aquifolium $\mathrm{L}$ & 15 \\
\hline Costanea sativa Miller & 13 \\
\hline Fraxinus spp. & 10 \\
\hline Pimus pinea L. & 9 \\
\hline Maloideae & 3 \\
\hline Colylus avefiana $\mathrm{L}$. & 1 \\
\hline Indeterminable & 24 \\
\hline Total & 768 \\
\hline
\end{tabular}

(Vaccaean, Sertorian and Roman stages) but most of the analysed charcoals came from the oldest layers of the settlement (Vaccaean stage). The origins of the charcoals were domestic fireplaces, ditches, post-holes, pits and burnt tools. Because of the sampling method (manual collection), the size of the analysed charcoal fragments from "Las Quintanas" was relatively large in size. The sample included fragments ranging from $2 \mathrm{~cm}$ to more than $10 \mathrm{~cm}$ long.

In general, the good preservation of the charcoals facilitated the identification of some taxa to the species level. In other cases, a poor state of preservation due to different taphonomic processes (vitrification, high fragmentation or insect and fungal degradation) made the distinctive anatomical features difficult to observe.

In the laboratory, the fracture of the charcoals along the three anatomical planes (transverse, longitudinal and tangential) necessary for fragment identification was performed manually. Then, the three observation sections were analysed under reflected light microscopy. Taxonomic identification was achieved by using atlases of wood anatomy (e.g.. Jacquiot. 1955; Schweingruber, 1990; García Esteban et al., 2003) and comparing the charred fragments with wood reference collections. In other cases, biogeographical information was considered when the anatomical identification of the charcoal was not conclusive.

\section{Results}

The microscopic analysis showed similar typologies in most of the charcoals, providing evidence of the presence of twelve woody taxa in the area (Table 1). Some microscopic features taken in consideration in the anatomical identification of charcoal fragments are shown in Fig. 2.

With regard to vegetation composition in this zone, the results show very similar richness in terms of the quantity of genera to what is currently present. In fact, the most representative genera of the sample, Pinus and Quercus, are the main genera present in the current inland iberian vegetation landscapes. However, two different floristic elements can be detected: (i) Mediterranean taxa like evergreen Quercus and conifers like P. pinaster, P. pinea and Juniperus spp. and (ii) microthermal/hygrophilous taxa like Pinus gr. sylvestris/nigra, Ilex aguifolium and Corylus avellana, most of which are currently absent closer to the archaeological site. The deciduous oaks would indicate a transition between the two previous groups and may be taken as an indicator of a sub-Mediterranean element. 

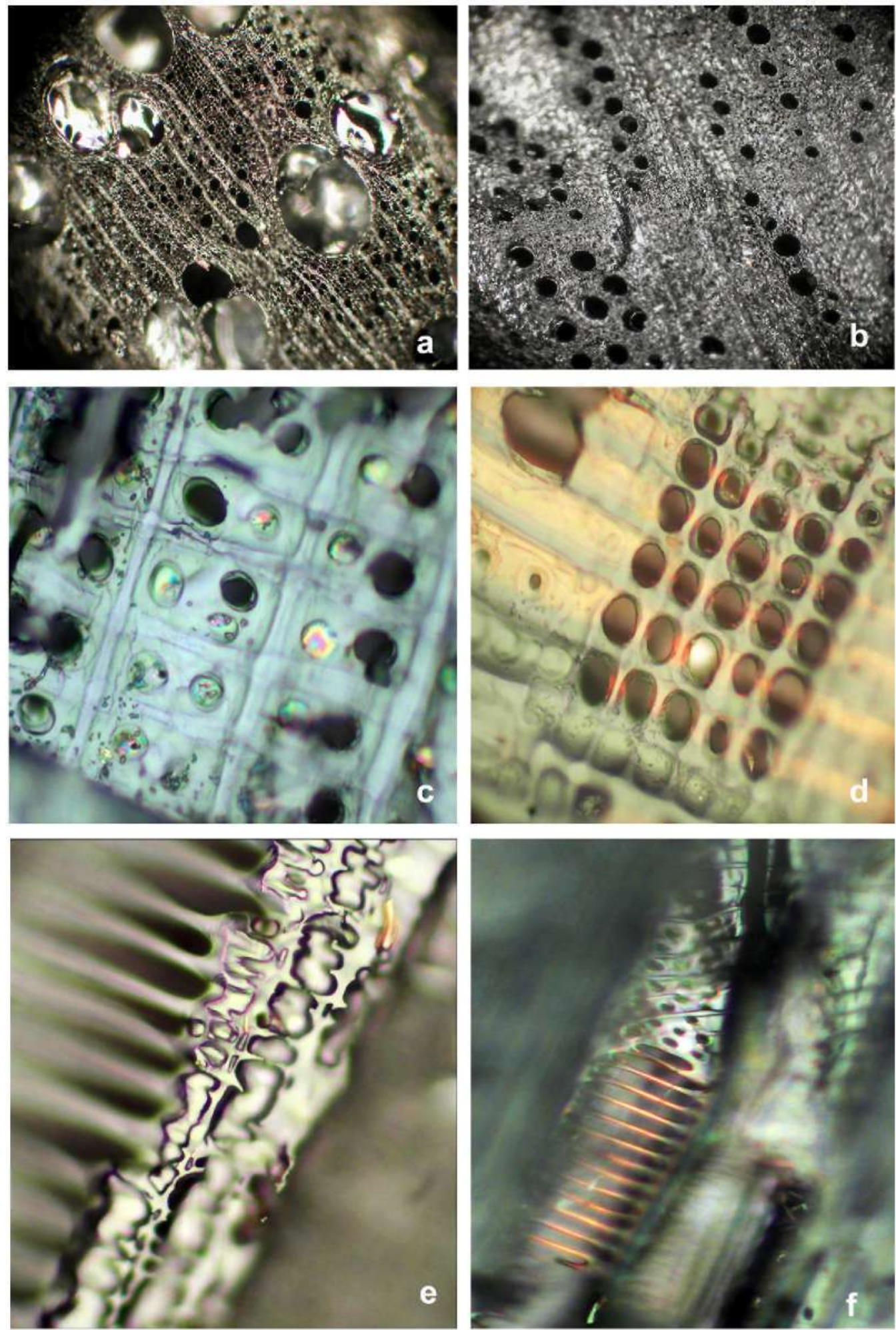

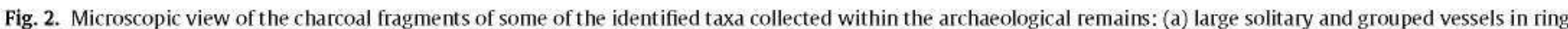

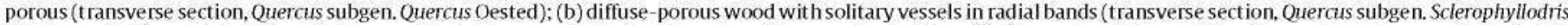

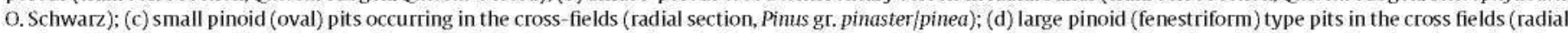

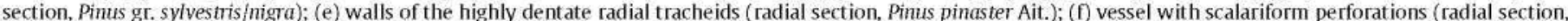
llex aquifolium L.).

\section{Discussion}

\subsection{Ecological and biogeographical interpretation of some results}

Due to the poor preservation of some of the carbonised material and the problematic differentiation of the wood of some species, some uncertainties in the identification of the charcoals occurred. In these cases, ecological and biogeographical information was useful to help interpret the findings. This was the case for the identification of the pines corresponding to section Sylvestris (i.e., $P$. sylvestris L., P. nigra Arn, and Pinus uncinata Mill), as some authors 
consider that the specimens of this group cannot be identified to the species level based in wood anatomy (for examples, see Schweingruber, 1990; Carcaillet and Vernet, 2001; Figueiral and Carcaillet, 2005). The current habitat of $P$. uncinata in high mountain environments above $1600 \mathrm{~m}$ restricts its distribution area almost completely to the Pyrenees and thus allows us to discard this species in the context of the present study. The ecological characteristics of the study area focused our diagnosis on the other two species ( $P$. sylvestris and $P$. nigra). Some of the anatomical features used by xilologists to differentiate these species are not conclusive (i.e., location of the resin ducts in the cross-section, dentation of the walls of the ray tracheids (Jacquiot, 1955; Peraza, 1964)). Because of this, the name Pinus gr. sylvestris/nigra was used. Another problem arose when trying to differentiate between the group comprising P. pinaster, $P$. pinea, Pinus halepensis and the Pinus canariensis species. Due to the ecology and present distributions of the last two species $(P$. canariensis is extinct today in the lberian Peninsula, whereas $P$. halepensis occurs in the eastern part of Spain), neither taxon was considered in this identification process. In order to differentiate between the other two Mediterranean pines, most authors (Jacquiot, 1955; Регаza, 1964; García Esteban and Guindeo Casasüs, 1989; Schweingruber, 1990; Figueiral, 1995; de Palacios de Palacios, 1997) agree on the use of the dentation of the ray tracheids (usually smooth in P. pinea and highly dentate in P. pinaster). When the poor preservation of the charred remains did not allow the use of this distinction, the sample was identified as Pinus gr. pinaster/pinea. In the case of the identification of the evergreen Quercus, the classification was focused on three species: (i) Cork oak (Quercus suber L.), which grows primarily in south-western Iberia on siliceous soils and in a temperate climate; (ii) Kermes oak (Quercus coccifera L.), which belongs to the subgenus Sclerophyllodris and is a typical element of maquis and coppice forests in the coastal area; (iii) Holm oak (Q. ilex subsp. ballota), which is adapted to Continental-Mediterranean environments characterised by severe drought and high summer temperatures. Therefore the charcoals identified as evergreen Quercus might correspond to Q. ilex subsp. ballota. Regarding the identification of deciduous Quercus, two marcescent species commonly occur in inland Spain, namely Quercus pyrenaica and Quercus faginea. However, as $Q$. pyrenaica acts as a calcifuge, the soil conditions in the available niches near Pintia point to $Q$ faginea as the most suitable oak species growing in the vicinity of the study site. Juniperus species could not be distinguished to species level based on their wood anatomy (Schweingruber, 1990), although considering the ecology of the genus and its current presence in the study area, three species must be considered. Spanish juniper (J thurifera) is well adapted to Continental climates and its forests are widely distributed across inland and eastern lberia, but the presence of other juniper trees, such as the common juniper ( $\mathrm{l}$. communis) or the Spanish cedar (J. oxycedrus), in the surrounding forests cannot be ruled out.

Although the taxonomic results reflect a low-diversity assemblage, it should be taken into account that most of the taxa identified are trees, while bushes and shrubs are poorly represented. This is due to the manual collection of the macro-remains in the archaeological site.

\subsection{The environments of the Duero basin during the Iron Age II as reconstructed from the anthracological record of Pintia}

The anthracological assemblage of Pintia confirms the historical presence of most of the tree species that are presently located in the extant stands living close to the study site, but it also shows a more diverse and complex forest landscape than what currently remains. First, the results show the relevance of genuine Mediterranean species in the forests, including $P$. pinaster, $P$. pinea, Juniperus and evergreen Quercus, In contrast, a great part of the assemblage corresponds to mesic taxa that presently do not grow or are very scarce in this region. The assemblage suggests that this last group, including Pinus gr. sylvestris/nigra, Corylus sp., Castanea sativa, I. aguifolium and, eventually, deciduous Quercus, which is currently characteristic of the Eurosiberian region and of mid- to high-mountain Mediterranean environments, was also locally present. Finally, the charcoal record also shows that other sub-Mediterranean species (i.e., those of intermediate ecological requirements between those of Mediterranean and Eurosiberian affinities), such as Q. faginea or juniper trees, probably J. thurifera, may also have been dominant in some of the forests growing during that period.

The difficulty to find suitable sites for pollen analysis (lakes, peatbogs) or macrofossil findings in Continental-Mediterranean lowlands of Central Spain, makes that very few previous consistent palaeobotanical works are available in the study area. The Holocene pollen records for the zone under study are restricted to two sites, one of which is an ancient lake in the zone of aeolian sediments of Tierra de Pinares (El Carrizal, Franco Múgica et al., 2005) and the other is situated at mid-altitude plateau of El Cerrato (Espinosa del Cerrato, Franco Múgica et al., 2001). Despite the fact that none of the records correspond exactly to the ecological characteristics of the area from where the charcoal assemblage may have originated, the records support the long-term regional dominance of the Mediterranean species detected in this study. Vegetation types have been very stable since the Lateglacial in the area and, as shown by the microscopic charcoal information, only late-Holocene human disturbances may have had some influence on the species composition at the end of the Holocene. Other anthracological and palaeoenvironmental studies carried out in other archaeological contexts also fit well in this model (e.g., Uzquiano, 1995; Mariscal, 1995; Mariscal et al., 1995; Ruiz Zapata, 1995; Yll, 1995).

Some distinctive anatomical features of the charred remains slightly improved the taxonomical resolution of the woody flora. Concerning pine species, $P$. pinaster and $P$. pinea have been detected in some archaeological units, but a great percentage of charcoal was identified only to the group level (i.e., Pinus gr. pinaster/pinea, Pinus gr. sylvestris/nigra and Juniperus spp.). Furthermore, some differences were detected in the species composition by comparing macrofossil and palynological records. This mostly affects Juniperus, which, after Pinus and Quercus, is the most represented group in the assemblage, whereas in the pollen records it is consistently but poorly represented. Its local presence was probably more important than previously hypothesised by regional palynological studies, but the human-mediated selection bias (Rubiales et al., 2011) or differences in the geographical and ecological characteristics among the studied sites may also cause this discrepancy.

However, it is worth noting that our anthracological study only recorded woody taxa and, consequently, non-forested landscapes may have alternated with trees over the Duero basin at that period. For example, Pliny and Strabo (as recorded by Wattemberg, 1959) report the existence of cattle and extensive Vaccaean cereal cultivation; conversely, Livy (also recorded in Wattemberg, 1959) describes the existence of important forest stands that the Vaccaean people strategically used to set ambushes for their enemies. As has been previously discussed, the degree of openness or proportion of these open-forested vegetation types remain to be determined on the basis of either the macro- or the microfossil evidence. Furthermore, as the site is located in a presumably active river basin. the geomorphological activity of the river should have constituted a major disturbance agent in the site. The analysis of the sandy deposits of Tierra de Pinares carried out by Bateman and DiezHerrero (1999) and Díez-Herrero et al. (2002) mostly record fluvial (and aeolian) activity during the early Holocene, but seasonal torrentiality and the existing loose lithology may account for a wider area of influence of riverine areas. 


\subsection{Evidence supporting the occurrence of the Mediterranean pinewoods in the area at Iron Age II}

The origin of the extensive Mediterranean pinewoods growing in the Duero basin has long been considered obscure by many of the plant biogeographers who have interpreted these landscapes (see Franco Múgica et al., 2005; Rubiales et al, 2011). Due to the great economic and strategic value of resin and kernels during the 20th century, pines have been intensely managed; they are thus frequently considered as anthropogenic. As a consequence, they are judged by some botanists as being of low interest from the conservation point of view (e.g., Navarro and Valle, 1987; Rivas Martinez, 1987). Although the problem of naturalness is not entirely resolved. both the anthracological data presented in this work at a local scale and previous palynological studies at the regional scale, indicate an early presence of these pines, suggesting that their wood has been widely used by humans at least since the onset of the historic times and that these forests have occurred in the Duero basin throughout the Holocene. Moreover, this late-Holocene record of Pintia fills a palaeobotanical information gap in the central zone of the Duero basin and provides species-level identification of the regional signal of Pinus as detected from pollen archives.

Mediterranean pines (including $P$. pinaster and $P$. pinea) are represented in the anthracological assemblage of Pintia as the most frequent group of taxa. Pinus is also the most important pollen type in the palynological records for the Duero basin throughout the Holocene. The site of El Carrizal (Franco Múgica et al., 2005) evidences a long-term persistence of the genus over sandy sediments; the same pattern occurs in the calcareous plains of the northern plateau (Espinosa del Cerrato, Franco Múgica et al., 2001)(Fig. 3), ог, during the early Holocene, in Quintana Redonda (García Antón et al., 1995 ) in the proximity of the Northern Iberian range. The sum of all of these findings strongly agrees with the geobotanical assumptions that the Pinus gr. pinaster/pinea stands were spontaneous and stable in the long term during the Holocene and of primary importance in the vegetal landscapes of the Duero basin (Gil et al., 1990; Costa et al., 1997). The important role of the pinewoods in Duero basin landscapes is also corroborated by the difficult regeneration of Quercus in the sandy sediments as this genus can only prosper when bedrock appears on the surface.

Regarding genetic studies of $P$. pinaster, one of the maxima of haplotypic diversity has been found in the northern Iberian plateau (Bucci et al., 2007); therefore, this area is considered as a "hotspot" of intraspecific diversity. However, the interpretations based on molecular markers of the origins of these populations and their putative colonisation pathways have remained controversial, essentially due to the lack of palaeobotanical evidence suggesting the existence of refugia as demonstrated for this species in other areas of lberia (i.e., Portuguese coast or south-eastern lberia). A recent study by de-Lucas et al. (2009) tested the hypothesis that the populations from the Duero basin originated from a contact zone between the Atlantic and Mediterranean gene pools of the species. Their results show that these populations cannot have completely originated from the Mediterranean, the Atlantic or a mixture of both gene pools but constitute a different gene pool by themselves. The archaeobotanical evidence from the present work, taken with the existing palaeoecological data, suggests the existence of a longterm origin of the species in the zone, but as no local nor regional Pleistocene fossil evidence exists for the species, it must still be considered as hypothetical. The situation based on the existing genetic data for the stone pine ( $P$. pinea) is much different: this pine species is highly depauperate, but one of the four haplotypes identified across its range is exclusively found in central Spain (Vendramin et al., 2008).

Some characteristics of the ecology of the stone pine like the apparent problems with its natural regeneration in the northern lberian plateau (Calama and Montero, 2007; Barbeito et al., 2008; Pardos et al., 2010) and the low genetically intraspecific diversity of this species, present some difficulties when interpreting its past allocation in the Duero basin. In the rest of the lberian Peninsula, $P$. pinea usually grows in sandy environments and at lower altitudes (e.g., coastal dunes, Martínez and Montero, 2004) and one would likewise expect to find the species on these substrates in the northem plateau. As a result this tree would be located, as at present, in sandy areas closer to Duero River where the water flow influence would result in a more suitable environmental condition for this species. On the other hand, $P$. pinaster, which is able to tolerate less limiting soils and continentality, may have had a wider distribution. However, in transition zones, both pines may have also developed mixed forest, creating similar landscapes to those that can be appreciated today.

These two species would have remained in inland Spain throughout the Holocene mainly as a result of their ecological adaptations to deep drained sandy sediments, nutrient-poor soils, drought tolerance, marked temperature contrasts and recurrent fires. In fact, in this area, P. pinaster, which has a non-serotinous lineage, shows ground fire-adaptions like P. pinea, such as a great thickness of bark (Tapias et al., 2004). The understory in the sandy sediments is sparse, and the occurrence of crown fires in these ecosystems is improbable. All these ecological adaptations to the Duero basin environmental conditions make $P$. pinaster and $P$. pinea suitable taxa for consideration in the selection of species in environmental restoration projects in the area.

Although marked oscillations in the Pinus pollen curve (Franco Múgica et al., 2005) and decreases in arboreal pollen have been reported since the last $1500{ }^{14} \mathrm{C}$ yr $\mathrm{BP}$ in the palynological works in the region, accompanied with an increase in the cereal pollen curves (Franco Múgica et al., 2001), Mediterranean pinewoods are still widespread in the area. This pattern does not fit with the generalised trend of other lberian forests, where the intensification of anthropic disturbances regimes implied the extinction of those arboreal stands. The maintenance and survival of these pinewoods in the lowlands of the Duero basin can be partly explained by the sustainable and traditional exploitation of pine resources carried out by the inhabitants of the central lberian Peninsula until the mid20 th century. So, even when the anthracological data from Pintia allows us to state that Mediterranean pines (both $P$. pinaster and $P$. pinea) were already present in the surroundings of this archaeological site during the first millennium $B C$, their long-term dynamics and range variations (transgressions or regressions) and the effects of the anthropogenic influence in these landscapes are difficult to assess and make very difficult to discern what is natural about those stands.

\subsection{River buffers as intergiacial reservoirs of woody elements: the late-Holocene role of highiand pines in the lowlands of the Duero basin}

The anthracological record from the Vaccaean village of Pintia indicates the presence of various hygrophilous/microthermal trees and shrubs such as Pinus gr, syivestris/nigra, I. aquifolium and $C$. avellana during the late Holocene near the settlement (Table 1). The regional palynological record from El Carrizal also showed the importance of microthermal taxa in the lowland northern Spanish plateau during the early Holocene. As a consequence of the subsequent climatic amelioration throughout the Holocene, the distribution of these formations was largely reduced in the area, suffering a probable vertical migration to the surrounding mountains.

At present, there are some relict enclaves closer to the study area (e.g. Cega River) where a number of coexisting Eurosiberian taxa that are much more broadly distributed in the mountains 

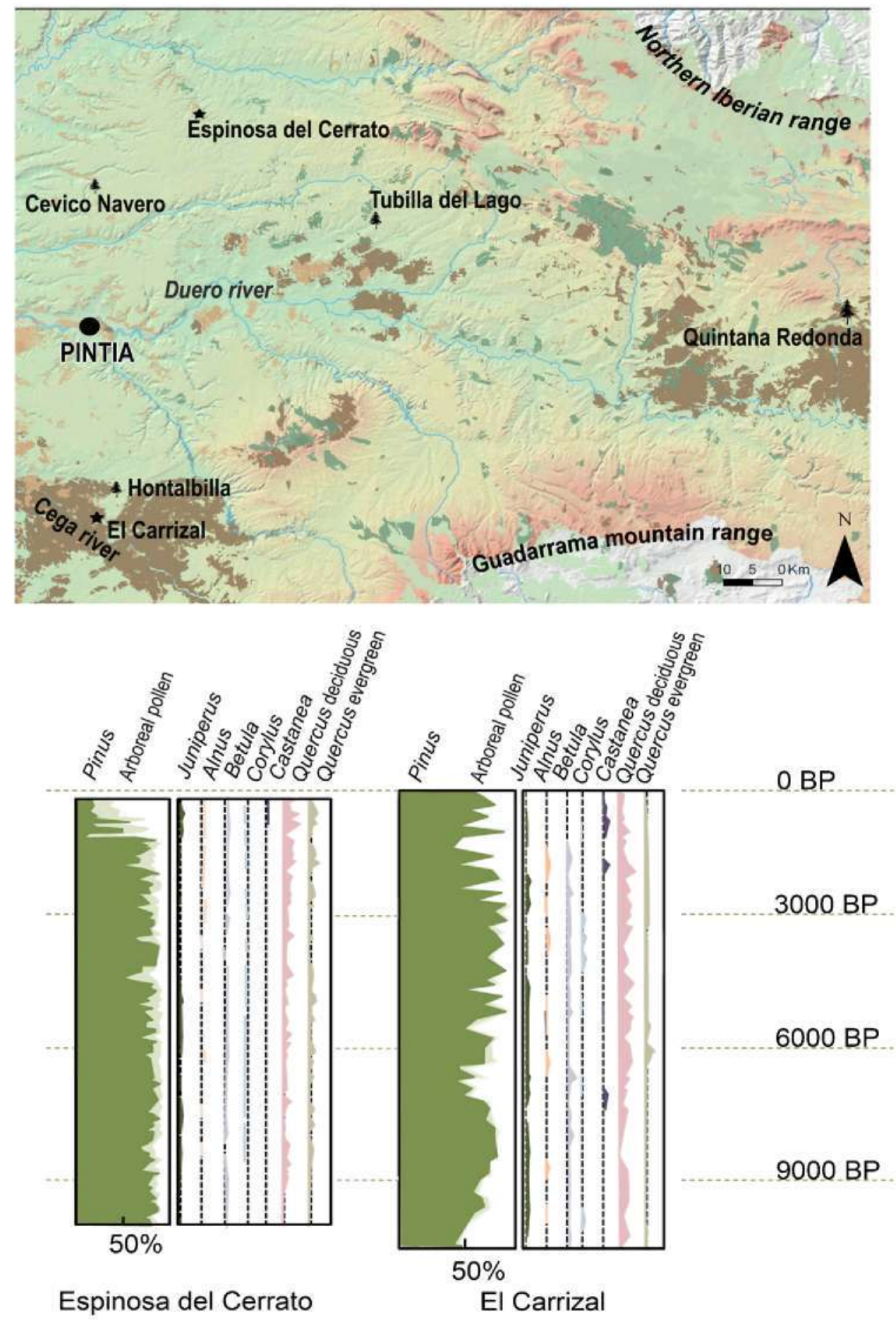

Espinosa del Cerrato

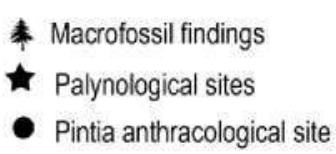

Pinus pinea

Pinus pinaster

Pinus sylvestris

Pinus nigra

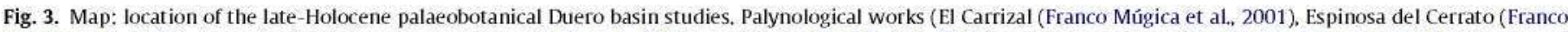

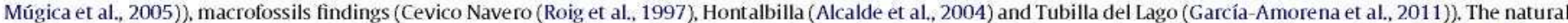

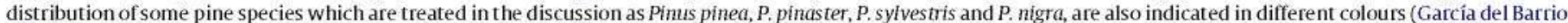

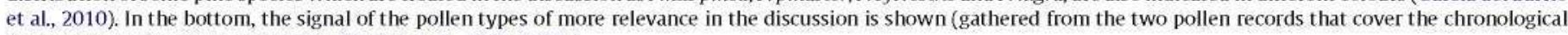
stage analysed in this paper (Franco Múgica et al., 2001, 2005)).

bordering the Duero basin, such as P. sylvestris, Betula alba L., Populus tremula L., C. avellana, Frangula alnus Mill. and Viburnum opulus L. (Guerra et al., 2006), can be found here within a genuine Mediterranean climate. The persistence of these communities along the Cega River is mainly attributed to the existence of favourable water conditions due to mantle groundwater dis- 
Table 2

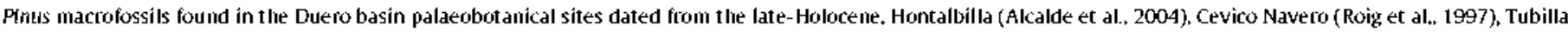
del Lago (García-Amorena et al., 2011) and Pintia (this work).

\begin{tabular}{|c|c|c|c|c|c|c|}
\hline \multirow{2}{*}{$\begin{array}{l}\text { Palaeobotanical sites } \\
\text { Type of macrofossil }\end{array}$} & \multicolumn{2}{|c|}{ Pinus gi, sylvestrisfnigra } & \multicolumn{2}{|c|}{ Pinus nigra } & \multirow{2}{*}{$\begin{array}{l}\text { Pintis pinaster } \\
\text { Woods }\end{array}$} & \multirow{2}{*}{$\begin{array}{l}\text { Pinlis pinea } \\
\text { Woods }\end{array}$} \\
\hline & Cones & Woods & Cones & Woods & & \\
\hline Hontalbilla & - & $\checkmark$ & - & - & $\checkmark$ & - \\
\hline Cevico Navero & - & - & , & , & - & - \\
\hline Tubilla del Lago & - & , & $\checkmark$ & - & - & - \\
\hline Pintia & - & , & - & & , & , \\
\hline
\end{tabular}

charges associated with sand and the narrowing of the river valley. which creates a cooler environment than the surrounding area (Guerra et al., 2006).

Pintia is located centrally on the banks of the Duero River. Recently, the channel has undergone pronounced changes caused by the rectification works related to cereal crops, vineyard exploitations and headwater basin regulations. This situation means that the floods have become much less important and that the water level has dropped markedly in comparison to Vaccaean times. During that period, the situation in the Duero basin may have been similar to that of the current Cega River basin, where greater water availability allowed the persistence of Eurosiberian forest in certain areas of the floodplain. Moreover, the human population of Pintia could have contributed significantly to the disappearance of these formations due to the suitability of these woody species for use as construction materials and firewood and the area's proximity to the human settlement (Rubiales et al., 2011).

The abundance of charcoal fragments of Pinus gr. syivestris/nigra is one of the most notable features of the Pintia assemblage as the two species that may have been present in the immediate environment during that period ( $P$. sylvestris, $P$. nigra) are extinct today. $P$. sylvestris has two small relict populations within a few tens of kilometres of the study area fed by high water table enclaves that attenuate the summer drought (Baró and Zorrilla, 1951; Soriano et al., 2002). As suggested previously, in the Pintia environment, this species could have been present in areas of high water availability near the Duero River or shady areas at the foot of the limestone hillslopes. The current relict populations have shown some genetic differentiation with respect to the largest of the surrounding mountains, probably reflecting fragmentation processes and genetic drift since the beginning of the mid-Holocene (RobledoArnuncio et al., 2005). Their presence in these environments during the late-Holocene is of particular significance, suggesting that current relict populations located in the lowlands of the Duero basin could have been more significant and less fragmented before the intensification of human impact on the landscape. P. nigra, a taxon with sub-Mediterranean character not currently present in the study area, could have undergone a similar process. Indeed, in the northern lberian plateau, available palaeobotanical information indicates that this species showed a much more extensive distribution in this area throughout the Holocene (Roig et al., 1997; Franco Múgica et al., 2001; Alcalde et al., 2004; García-Amorena et al., 2011), often until the end of the mid-and even late-Holocene (see Table 2 and Fig. 3).

The suggested aridity increase detected in the northern plateau during the second half of the Holocene (Franco Múgica et al., 2001. 2005 ) could also have adversely affected these two pine species. Conversely, the pollen record shows how these communities were very stable over the Holocene until the intensification of human impact caused their decline (Franco Múgica et al., 2001). Previous studies have indicated that the fires could have played a significant role in triggering these extinctions in other areas of central Spain (Franco Múgica et al., 2001; Rubiales et al., 2007, 2010) as these species have a very limited tolerance to fire and are frequently replaced by resprouter species (Rodrigo et al., 2004).
The anthracological record of Pintia shows how the natural environment close to the human settlement comprised species with mostly Eurosiberian or sub-Mediterranean distributions that are now extinct in the area. This information has to be carefully taken into account when planning future projects aiming to restore the vegetation prior to the intense anthropogenic disturbance of the last two millennia. The persistence of Eurosiberian taxa in the best preserved riparian environments of the lberian Peninsula (Lara et al., 2004) shows how these sites can behave as "interglacial refuges" (Bennett and Provan, 2008) for some taxa with wider distributions in the lower areas of the Mediterranean region during colder periods. The probable existence of a genuine gene pool in these pine populations reinforces the importance of conservation and management directed toward achieving this goal.

\subsection{Conclusions}

Archaeological information can be a useful tool to reconstruct forest history and determine future forestry management strategies. This method can confirm the prehistoric presence of some taxa whose natural occurrence in the area has been subject to debate, as has been the case of Mediterranean pines ( $P$. pinaster $P$. pinea) in the Duero basin near Pintia. Furthermore, this work demonstrates the presence of microthermal/hygrophilous vegetation refugia through the interglacial period in inland Spain through historic times. The location of such areas has, until now, been presumably linked to great terrain features such as mountains (Bennett et al., 1991), leading to underestimation of the role that river buffers may have played in the long-term diversity of woody taxa. These relict formations have noticeably decreased in the last millennia, leaving only scattered examples, such as those from the Cega River.

At the present time, European and Spanish regional environmental policies, such as the Habitat Directive or different LJFE projects, promote the restoration of riparian ecosystems and forest cover in an attempt to create functioning ecosystems that are as similar as possible to the original landscapes prior to the substantial anthropogenic disturbances of recent millennia. Palaeoecology is an important source of information to achieve these goals; for example, allowing us to discern which taxa are native, which have been introduced and how the impact of human cultures was in the landscapes (e.g., Willis and Birks, 2006; van Leeuwen et al., 2008; Valsecchi et al., 2010). Pintia's anthracological results highlight the need to conserve the relict Eurosiberian formations, such as the Cega River, as a snapshot of the vegetation landscapes of the recent past near the study area. The results also suggest Mediterranean pinewoods ( $P$. pinaster and $P$. pinea) as suitable species for use in regional plans of conservation and restoration of forest cover.

\section{Acknowledgements}

We would like to thank Carlos Morla for his constructive comments and support during the preparation of the work Cristina Górriz for the careful preparation of the archaeological material and lván Torres and Salvador Rodríguez for their throughout revision of the English manuscript. We are also grateful to two 
anonymous reviewers for their helpful suggestions on the first draft of this article. LH held pre-graduated grants from the UVA and UPM. CMM holds UPM pre-doctoral grant. Funding was provided by grants from the Ministerio de Ciencia e Innovación, Spain projects (CGL2008-06005/BOS-SENSCOM-, HAR2010-21745-C0301 and CGL2009-06988-JBERVELD) and from the Junta de Castilla y león.

\section{References}

Alcalde, C., García-Amorena, I., Gómez Manzaneque, F., Maldonado, J., Morla, C.. Postigo, J.M. Rubiales, J.M., Sánchez He[nando, L.J., 2004. Nuevos datos de carbones y maderas fósiles de Pimus pinaster Aiton en el Holoceno de la Península Ibérica. Invest. Agrar.: Sist. Recur. For. Fuera de serie, 152-163.

Álvarez-Sanchís, J.R, 2005. Oppida and Celtic society in western Spain. e-Keltoi: J. Interdiscipl. Celt. Stud. 6, 1-31.

Barbeito, I., Pardos, M.. Calama, R. Cañellas, I. 2008. Eftect of stand structute on stone pine (Pinus pinea $L$ ) regeneration dynamics. Forestry 81, 617-629.

Baró, F. Zorrilla, F., 1951. Pinares de la meseta sur del Duero (Castilla la Vieja) Mapa agronómico nacional. Hoja 429. Ministerio de Agricultura. Navas del Oro (Segovía), España.

Bateman, M.D., Diez-Herteto, A., 1999. Thermoluminiscence dates and palaeoenvironmental information of the late quaternary sand deposits. Tierra de Pinares, Central Spain. Catena 34, 277-291.

Bennassat, B., 1967. Valladolid en el siglo de Oto, Ayuntam iento de Valladolid, Valladolid. Spain.

Bennett, K,D., T2edakis, P.C., Will is, K, l., 1991, Quaternary refugia of notth Eu ropean trees. J. Bíogeogr. 18, 103-115.

Bennett, K.D., Provan, J., 2008. What do we mean by 'refugia'? Quaternary Sci. Rev 27. $2449-2555$

Blanco Abril, J., 2003. Nuestros bosques de Castilla y León. Su historia y evolución ed. Junta de Castilla y Lé́n, Consejelía de Medio Ambiente. España.

Bucci, G. González-Mattínez, S.C., Le Provost, G., Plomion, C., Ribeiro, M.M., Sebastiani, F., Alía, R., Vendramin, G.G., 2007. Range-wide phylogeography and gene zones in Pinlis pinaster Ait, revealed by chloroplast microsatellite markers. Mol Ecol. 16,2137-2153.

Calama, R. Monteco, G., 2007. Cone and seed production from stone pime (Pinus pinea L.) stands in Cent ral Range (Spain). Eur. J. Forest Res, 126 (1), 23-35.

Calonge Cano, C., 1987. El Complejo ecológico y la organización de la explotación torestal ell la Tietra de Pinates segoviana. Exma. Diputación Provincial de Segovia, 347.

Calonge Cano, G., 1998, La tietra de pinares segoviana. Medio Ambiente en Castilla y Léón 5, 15-35.

Calonge Cano, G., Santos, J.M., 2006 . Repoblaciones y "protecciones" de los enc inares ibéricos hasta el siglo XX. Los ejemplos expresivos de Castilla y Léón. Instituto unive rsitario de Geografia. Universidad de Alicante. Invest igaciones geográficas 41, 33-48.

Carcaillet, C., Vernet, J.L, 2001, Comments on "The Full-Glacial Forests of Central and Southeastern Europe" by Willis et al. Quaternary Res. 55, 385-387.

Cartión, IS., Navatro, C., Navarto, J., Manuera, M., 2000. The distribution of cluster pine (Pinus pinaster) in Spain as derived from palaeoecological data: relationships witl pliytosociological classitication. Holocene 10 (2), 243-252.

Cartión, I.S. Fernández, S. Jiménez-Moreno, G., Fauquette, S., Gil-Romera, G. González-Sampériz, P.. Finlayson, C., 2009. The historical origins of aridity and vegetation degradation in sout heasterin Spain. J Arid Environ. 74, 731-736.

Conedera, M., Krebs, P., Tìnner, W., Pradella, M., Torriani, D., 2004. The cultivation of Castanea sativa (Mill.) in Europe, from its origin to its diffusion on a continental scale. Veg. Hist. Archaeobot. 13, 161-179.

Costa, M., Morla, C., Sainz, H., 1997. Los bosques ibéricos. Una interpretación geobotámica, ed, Planeta. Barcelona.

de Palacios de Palacios, P., 1997. Anatomía de maderas de coníferas a nivel de especie. Región Norteamericana y Europea. PhD Thesis. Escuela Técnica Superior de Ingenieros de Montes. Madrid.

de-Lucas, A.I., González-Martínez, S.C., Hidalgo, E., Bravo, F., Hevertz, M., 2009. Admixture, one-source colonization or long-term persistence of maritime pine in the Castilian Plateau? Insights from nuclear microsatellite markers. Investigacion Agraria: Sistemas y Recursos Forestales 18, 3-12.

Díez-Hertero, A, Bateman, M.D. López-Sáz, J.A, vega Salamanca, J., 2002. Procesos eólicos Tardiglaciares en la submeseta septentrional: cronología del manto arenoso de Tierra de Pinares. Aportaciones a la Geomortología de España ell el inicio del tercer milenio in Pérez-González A., Vegas J., Machado M.J. (Eds). pp $167-175$.

Figueiral, I., 1995. Clarcoal analysis and the history of Pinus pinaster (cluster pine) in Portugal. Rev. Palaeobot. Palynol 89, 441-459.

Figueiral, I., 1996. Wood resou rces in north-west Portugal: their availability and use trom the late Bronze Age to the Roman period. Veg. Hist. Archaeobot. 5, 121 - 129.

Figueiral, I., Carcaillet, C., 2005. A review of Late Ple istocene and Holocene biogeography of highland Mediterranean pines (Pinus type sylvestris) in Pottugal, based on wood charcoal. Quaternary Sci. Rev. 24, 2466-2476.

Font Quer, P., 1954. La vegetación. Ir: Terán, M. (Ed.), Geografia de España y Poitugal, 2. Montaner y Simón. Barcelóna, pp. 145-271.

Franco Múgica, F., García Antón, M., Maldonado Ruiz, J., Morla Juaristì, C., Sainz ollero. H., 2001. The holocene history of pinus forests in the Spanish northen meseta. Holocene 1] (3), 343-358.
Franco Múgica, F, García Antón, M, Maldonado, J, Morla, C, Sainz Ollero, H, 2005. Ancient pine forest on inland dunes in the Spanish northern meseta. Quaternary Res. 63, 1-14.

Garcia-Amorena, I, Rubiales, J,M, Moreno Amat, E, lglesias González, R, Gómez Manzaneque, $F, 2011$. New macrofossil evidence of Pinus nigia Arnold on the Northeri Iberian plateau during the Holocene. Rev. Palaeobot. Palynol. 163, $281-288$.

Ciarcía Antón, M., Franco Mógica, F., Maldonado Ruiz, J., Morla Juaristi, C., Sainz Olleto, H. 1995. Una secuencia polímica en Quintana Redonda (Soria). Evolución holocena del tapiz vegetal en el Sistema Ibérico Septentrional. Anales del Jardín Botánico de Madrid 52 (2).

García del Barrio.J.M., Auñón, F.J., Sănchez de Ron, D. 2010. SIG de especies Forestales. Genfored. (http: //www inia.es). CIFoR-INIA.

García Esteban, L., Guindeo Casasús, A. 1989. Anatomía de Las Maderas de Fiondosas Española5. A.I.T.I.M., Madrìd.

García Esteban, L., Guindeo Casacús, A, Peraza Oramas, C, de Palacios de Palacios, P. 2003. La madera y su Anatomía. Coedición Fundación Valle de Salazar. Ediciones Mundi-Prensa A.IT.I.M. Madrìd.

García Fernández, J., 2004. La explotación tradicional en “La tierta de Pinares" segoviana. Investigaciones Geográficas 35, 5-23.

Gil, L, Gordo, J., Alía, R., Catalán, J., Pardos, J.A., 1990. Pintis pinaster Ait, en el paisaje vegetal de la Península Ibérica. Ecología 1, 469-496.

Cill, L., 1991. Consideraciones históricas sobre Pimus pinaster Aiton en el paisaje vegetal de la penímsula Ibérica, Est. Geogt. 202 (2), 5-27.

Cill, L. Fuentes-Utrilla, P. Soto, A. Cervera, MT. Collada, C., 2004. Phylogeography: English elm is a 2,000-yeaf-old Roman clone. Nature 431, 1053.

Gil, L., Torre, M. (Eds.), 2007. Atlas Forestal de Castilla y León, Valladolid. Spain.

Gillerra, J.C. Giarcía de Celis, A.J., Arroyo, P. 2006. Estructura y dinámica de una poblaciôn de Betula aba L, en las Ilanu ras sedimentatias de la cuenca del Dueto (tramo medio del río Cega - Cuéllar, Segovia-). Serie Cieográfica - Biogeografia: Distribuciones, Dinámicas y Diversidad 13,65-79.

Hoptinet, $H_{1}$ 1954, La evolución de los bosques de Castilla la Vieja en tiempos histócicos. Estudios Geográficos 54, 415-430. In Gil, L., 2008. Pinares y rodenales. La diversidad que no se ve. Discurso académico. Ed. Real academia de la lngeniería. Madrid. España.

Huguet del Villat, E., 1925. Avance geobotánico sobre la pretendida estepa central de Espaî̀a I, II y III y IV. Ibética 13,576:281-283:577:297-302:579: 328-333: 580: 344-351.

Jacquiot, C., 1955. Atlas d'anatomie des Bois des Conifères, Centre Technique du Bơis, Paris.

Lara, F. Garilleti, F., Calleja, J.A. 2004. La vegetación de ribera de la mitad norte española. Monografía del CEDEX 81, ed. CEDEX, Madrid

Lewis, P.R., Jones, G.D.B., 1970. Roman gold-mining in north-west Spain. J. Roman Stud. 60, 169-185

López-Sáez, J.A., López-Merino, L., Alba-Sănchez, F., Pérez-Díaz, S., Abel-Schaad, D., Carrión, J.S. 2009. Late Holocene ecological history of Pintis pinaster torests in the Sierra de Gredos of central Spain. Plant Ecol. 206 (2). 195-209.

Mariscal, B., 1995. Análisis polínico de los yacimientos de la Edad de Hierro de EI Soto de Medinilla (campaña 1989-1990) y El Certo de la Mota ell Medina del Campo, Valladolid, In: Delibes, G., Romero, F., Morales, A. (Eds.), Arqueología y Medio ambiente; el primer milenio a. C en el Duero medio. Ju nta de Castilla y Leôin, pp. 337-350.

Mariscal, B. Uzquiano P. Cubero C 1995 Paisaje y recursos del valle del Duero durante el primer milenio antes de Cristo a traves de la Paleoetnobotánica. In: Delibes, G., Romero, F., Morales, A. (Eds.), Arqueología y Medio ambiente: el primer milenio a. C. en el Duero medio. Junta de Castilla y León. pp. 417-454.

Mart inez, F., Montero, J., 2004. The Pinus pine L. woodlands along the coast of southwesteril Spain: data for a new geobotanical interpretation. Plant Ecol. 175, 1-18

Navarro, F. Valle, C.J., 1987. Castilla y León in Peinado. In: Rivas Martínez, M.S. (Ed.) La Vegetación de España. Serv. Publ. Univ. Alcalá, p. 544.

Pardos, M., Puértolas, J., Madrigal, G., Gatriga, E, De Blas, S., Calama, R., 2010. Seasonal changes in the physiological activity of regeneration under a natural light gradient in a Pinus pinea regular stand. Forest Systems: special Issue on G lobal change and mediterranean pines $19(3), 367-380$.

Peraza, C., 1964. Estudio de madera de coníferas de España y Norte de Marnuecos. IFIE.

Reimer, P.J., Baillie, M.G.L., Bard, E., Bayliss, A., Beck, J.W., Blackwell, P.G., Bronk Ramsey. C., Buck, C.E., Burr, G.S. Edwards, R.L., Friedrich, M., Grootes, P.M. Guilderson. T.P., Hajdas, I., Heaton. T.J., Hogg. A.G., Hughen, K.A., Kaiser, K.F., Kromer, B., McCormac, F.G. Manning, S.W. Reimer, R.W. Richards, D.A. Southon, J.R., Talamo, S., Turney. CS.M., van der Plicht, J., Weylienmeyer, C.E, 2009 . INTCALO9 and MARINEO9 radiocarbon age calibration curves, 0-50,000 vears cal BP. Radiocarbon 51, 1111-1150.

Rivas Martímez, S. 1987. Mapa de las series de vegetación de España, escala 1:400,000. Mínisterio de Agricultura, Pesca y Alimentación. KONA, Madrid, Spain

Rivas Martinez, S., 2007. Mapa de series, geoseries y geopermaseries de vegetación de Espaîa (Memoria del Mapa de Vegetacion Potencial de Espana). Parte I.

Robledo-Ainu ncio, J.]., Collada, C., Alía, R., Gil, L, 2005, Genetic structure of montant isolates of Pinus sylvestis L. in a Mediterranean refugial area. J. Biogeogr. 32. 595-605.

Rodrigo, A., Retana, J., Picó, F.X., 2004. Direct regeneration is not the only response of Meditertantean forests to lange fires. Ecology 85, 716-729.

Roig, S. Gómez Manzaneque, F., Masedo, F., Morla, C., Sánchez Hernando, L.l., 1997. Estudio paleobotánico de estróbilos y maderas subfósiles holocenas en 
el yacimiento de Cevico Navero (Palencia, España). All. Jard. Bot. Madrid 55, 111-123.

Rubiales, J.M., Gatcía-Amotena, I, Génova, M., Gómez Manzaneque, F, Morla, $C_{\text {, }}$ 2007. The Holocene history of highland pine torests in a submediterranean mountain: the case of Gredos mountain range (Iberian Central range, Spain). Quaternary Sci. Rev. 26, 1759-1770.

Rubiales, J.M., García-Amorena, I., Hernández, L, Génova, M., Martínez, F. Gómez Manzaneque, F., Morla, C., 2010. Late quaternary dynamics of pinewoods in the Ibetian mountains. Rev. Palaeobot. Palynol. 162, 476491.

Rubiales, I.M., Hernández, L, Romero, $F_{.}$Sanz, $C_{.}, 2011$. The use of torest resources in central Iberia during the late Iron Age. Insights from the wood charcoal analysis of Pintia, a Vaccaean oppidam. J. Archaeol. Sci. 38, 1-10.

Ruiz Zapata, M.B., 1995. Análisis polínico del yacimiento de Soto de Medinilla: campaña de 1986-87 en el poblado vacceo in: Delibes, G., Romero, F., Morales, A. (Eds.). Arqueología y Med io ambiente: el primer milenio a. C. ent el Dueto medio. Junta de Castilla y León, pp. 351-356.

Sanz Mínguez, C., Romero Carnicero, F. (Eds). 2007. En los extremos de la región vaccea. Ed. Caja Es paña, León.

Schulten, A. 1963. Geografía y Ethnografia Antiguas de la Península. Ibérica, vol. II. C.S.IC. Inst. "Rodrigo Caro" de Arqueologia, Madrid.

Schweingruber, F.H., 1990. Anatomie Europaischer Holzer. Paul Haupt Publishers, Berne/Stuttgart.

Soriano, G, Gastón. A, Batiego, P., Herrero, B., García-Viñas, J.1., 2002, Catálogo florístico del barranco del río Cega (Segovia, España). Ecología 16, 153220 .
Tapias, R., Climent, J., Pardos, J.A, Gil, L, 2004, Life histoties of Mediterramean pines. Plant Ecol. 171 (1-2), 53-68.

Uzquiano, $P_{*}$ 1995. El valle del Dueto en la Edad del Hierro; el aporte de la Antracología in: Delibes, G. Romero, F. Morales, A. (Eds.). Arqueología y Medio ambiente: el primer milenio a. C. en el Duero medio. Junta de C.astilla y León. pp. $395-416$.

Valsecchi, V., Carraro, G., Conedera, M., Tinner, W., 2010. Late-Holocene vegetation and land-use dynamics in the Southern Alps (Switzerland) as a basis for nature protection and totest management. Holocene 20, 483-495.

van Leeuwen, J.F.N., Froyd, C.A., van der Knaap, W.O., Coffey, E.E., Tye, A., Willis, K.J. 2008. Fossil pollen as a guide to conservation in the Galapagos. Science 322. 1206.

Vendramin, G., Fady, B., Gonzalez-Martınez, S.C., Feng Sheng Hu, Scotti, I., Sebastiani, F. Soto, A., Petit, R.J., 2008. Genetically depauperate but widespread; the case of an emblematic Mediterranean pine. Evolution 62, $680-688$.

Wattemberg, F., 1959, La región vaccea: celtiberismo y romanización en la cuenca media del Duero. In: Biblioteca Prehistórica Hispánica, II. CSIC y Diputación Provincial de Valladolid, Madrid.

Willis, K.J., Birks, H.J.B., 2006. What is natural? The need for a long-term perspective in biodiversity conservation. Science 314, 1261-1265.

Willkomm, M., 1896. Die Vegetation der Erde. Grundzüge der Pflanzen Vetbreitung auf der Iberischen Halbinsel. Wilhelm Engelmann, Leipzig.

YII, E., 1995. Análisis polínico de los yacímientos de la Edad del Hierro de Soto de Medinilla, La Era Alta y La Mota (Valladolid). In: Delibes, G., Romero, F., Morales. A. (Eds.). Arqueología y Medio ambiente: el primer milenio a. C. en el Duero medio, Junta de Castilla y León, pp. 417-454. 